\title{
Late-summer Disease Symptoms in Western Washington Red Raspberry Fields Associated with Co-Occurrence of Phytophthora rubi, Verticillium dahliae, and Pratylenchus penetrans, but not Raspberry bushy dwarf virus
}

\author{
Jerry E. Weiland, ${ }^{\dagger}$ United States Department of Agriculture-Agriculture Research Service (USDA-ARS), Horticultural Crops Research Lab- \\ oratory, Corvallis, OR 97330; Chris Benedict, Washington State University Whatcom County Extension, Bellingham 98225; Inga A. Zasada, \\ Carolyn R. Scagel, Bryan R. Beck, Anne Davis, Kim Graham, Amy Peetz, and Robert R. Martin, USDA-ARS, Horticultural Crops Re- \\ search Laboratory; and Jeremiah K. S. Dung, Andres Reyes Gaige, and Lindsey Thiessen, Oregon State University, Department of Botany \\ and Plant Pathology, Corvallis 97331
}

\begin{abstract}
Sixty percent of the $\$ 109$ million processed red raspberry industry of the United States occurs in northern Washington State. In 2012, late-summer symptoms of vascular wilt and root disease were observed in many raspberry plantings. These symptoms were initially attributed to Verticillium dahliae. However, diagnostic tests for the pathogen were often contradictory and other soilborne pathogens (Phytophthora rubi and Pratylenchus penetrans) or Raspberry bushy dwarf virus (RBDV) might also have been involved. Therefore, a survey was conducted in 2013 and 2014 to (i) establish the incidence and soil population levels of $V$. dahliae in red raspberry production fields, (ii) compare among diagnostic methods and laboratories for detecting and quantifying $V$. dahliae from raspberry field soil, and (iii) assess which pathogens are associated with latesummer disease symptoms of raspberry. Plant and soil samples were collected from 51 disease sites and 20 healthy sites located in 24 production fields. Samples were analyzed for the presence and quantity of each pathogen using traditional plating and extraction methods (V. dahliae, P. rubi, and $P$. penetrans), quantitative polymerase chain reaction (qPCR) (V. dahliae and $P$. rubi), and enzyme-linked immunosorbent assay (RBDV). Results showed that $V$. dahliae was present in $88 \%$ of the production fields and that detection of the pathogen differed by method and

by laboratory: qPCR detected $V$. dahliae in the soil from approximately three times as many sites (51 of 71 total sites) as by plating on NP10 semi-selective medium (15 of 71 total sites). Soil populations of $V$. dahliae were slightly greater at disease sites, but the pathogen was detected with similar frequency from healthy sites and it was rarely isolated from diseased plants (4\%). P. rubi, P. penetrans, and RBDV were also common in production fields $(79,91$, and $53 \%$ of fields, respectively). Both $P$. rubi (soil and root samples) and $P$. penetrans (root populations only), but not RBDV, were more frequently found at disease sites than healthy sites, and the amount of $P$. rubi detected by qPCR was greater from disease sites than healthy sites. In addition, P. rubi was isolated from $27 \%$ of the symptomatic plants located at disease sites. Regardless of detection method, $V$. dahliae, $P$. rubi, and $P$. penetrans, either with or without RBDV, were more likely to co-occur at disease sites $(73 \%)$ than healthy sites (35\%), suggesting that a soilborne disease complex is present in raspberry production fields. Results indicate that $P$. rubi is the primary pathogen most strongly associated with late-summer symptoms of disease, but root populations of $P$. penetrans and higher soil populations of $V$. dahliae may also be of concern. Therefore, disease control methods should focus on all three soilborne pathogens.
\end{abstract}

Washington State, in the northwest United States, produces almost $60 \%$ by weight of the processed red raspberry (Rubus idaeus L.) in the nation (United States Department of Agriculture National Agricultural Statistics Service 2017). In 2016 alone, Washington produced over 31 million $\mathrm{kg}$ of fruit valued at $\$ 58$ million. There are 3,845 ha in production in Washington, of which Whatcom County, in the northwestern region of the state, produces over $95 \%$ of the state's total.

Red raspberry plants are affected by several pathogens that can severely reduce crop productivity and the longevity of field plantings. Because prime land for raspberry production is limited, most fields are immediately replanted to raspberry after the previous planting has been removed due to declining health and productivity or to change cultivars (Rudolph and DeVetter 2015; Stewart et al. 2014). Over time, growers have noticed that the productive lifespans of subsequent plantings have diminished from $\geq 12$ years to about 5 to 7 years (Gigot et al. 2013; Rudolph and DeVetter 2015). At the end of their lifespan, raspberry plantings often show symptoms of root and vascular disease,

${ }^{\dagger}$ Corresponding author: J. Weiland; E-mail: Jerry.Weiland@ars.usda.gov

Funding: Financial support was provided by the Washington Red Raspberry Commission and by the USDA-ARS Current Research Information System 2072-22000-043-00D.

Accepted for publication 17 November 2017.

This article is in the public domain and not copyrightable. It may be freely reprinted with customary crediting of the source. The American Phytopathological Society, 2018. including reduced primocane (cane) production, stunting and low vigor, chlorosis, wilting, reduced yields, and die-out. Root health in these older plantings is often noticeably compromised and both Phytophthora rubi (W. F. Wilcox \& J. M. Duncan) Man in 't Veld and Pratylenchus penetrans (Cobb) Filipjev \& Schuurmans are thought to be the two primary soilborne pathogens (Gigot et al. 2013). A disease complex involving these, and possibly other soilborne pathogens in the genera Cylindrocarpon, Rhizoctonia, Fusarium, Pythium, and Verticillium, is suspected of driving the decline in raspberry productivity and longevity in the region (Rudolph and DeVetter 2015; Schilder and Gillett 2007; Weber and Entrop 2017; You et al. 2006).

P. rubi, the cause of Phytophthora root rot, is the most serious pathogen of red raspberry worldwide (Duncan et al. 1991; Wilcox and Cooke 2017). It is common in most Washington raspberry fields, where it can cause up to $100 \%$ plant mortality in heavy or saturated field soils (Gigot et al. 2013). Infection is thought to be favored by cool temperatures and wet soils (Duncan and Kennedy 1989; Wilcox et al. 1993), which are common conditions in the winter and spring in western Washington. Root rot symptoms begin early in the growing season and are the most severe in June as fruit begins to ripen. Symptoms include the development of chlorotic, reddish, scorched, or wilted leaves; thin canopy; stunting; reduced cane production; shriveled fruit; and reddish-brown root lesions that may extend up into the canes. Plant death occurs when enough of the larger roots and canes are girdled.

$P$. penetrans, the root lesion nematode, is a cosmopolitan pest of raspberry and is found widespread in Washington raspberry fields (Gigot et al. 2013; Zasada et al. 2017). Root lesion nematodes migrate and feed within small-diameter roots, where they cause necrotic lesions and reduced fine root abundance (McElroy 1992). Severe 
root damage reduces water and nutrient uptake, leading to aboveground symptoms of stunting and leaf chlorosis. Most of the raspberry cultivars grown in Washington are susceptible to $P$. penetrans (Zasada et al. 2015). If this nematode is not managed, up to a $75 \%$ reduction in plant establishment can occur in replanted fields (Zasada et al. 2015).

Management of both $P$. rubi and $P$. penetrans currently relies on untarped, preplant fumigation with Telone C-35 (65\% 1,3-dichloropropene + $35 \%$ chloropicrin) with supplemental nematicide (oxamyl) or fungicide (mefenoxam and phosphorous acid) applications as needed (Rudolph and DeVetter 2015; Walters et al. 2017; Zasada and Walters 2016). Most fumigation in Washington is conducted in late summer to early fall after the old planting has been removed, and new raspberry plants are transplanted into the field in the following spring (Walters et al. 2017). Prime land for raspberry production is limited, and growers often replant into the same fields without crop rotation or the removal of large woody root debris from the previous crop (Kroese et al. 2016; Rudolph and DeVetter 2015). These practices may limit the efficacy of preplant fumigation and allow soilborne pathogen inoculum from the previous crop to survive in the soil until replanting occurs.

Viruses are also a major concern for this industry and can likewise limit the productive lifespan of plantings. Raspberry bushy dwarf virus (RBDV) is an RNA virus that is common in most raspberry production areas and is transmitted by pollen or seed (Martin 1998; Quito-Avila et al. 2014). Infection can lead to leaf chlorosis and stunting, and may cause fewer drupelets to set, resulting in fruit that crumbles during harvest. The virus is a severe problem in Washington, particularly when occurring in mixed infections with aphid-transmitted viruses such as Raspberry leaf mottle virus (RLMV) and Raspberry latent virus (RpLV) (Quito-Avila et al. 2014). Management is focused on planting certified, virus-free material, controlling the aphid vector of RLMV and RpLV, and on replanting after infection has spread throughout most of the field (Quito-Avila et al. 2014).

In 2012, growers in Washington increasingly observed a collection of symptoms in raspberry plantings that were considered atypical for Phytophthora root rot, nematodes, or RBDV. Symptoms of leaf chlorosis and scorch, wilting, and overall plant stunting appeared in late summer (August to September), when P. rubi is thought to be less active (Wilcox et al. 1993). Additionally, affected plants were located on drier, sandier sites where Phytophthora root rot had not previously been a problem. In severe cases, individual canes or entire plants would suddenly wilt and die, which is not indicative of either nematode or virus infection. Verticillium dahliae Kleb. was detected in the soil and isolated from symptomatic plants in three production fields by two diagnostic laboratories. The pathogen was also detected in the soil from several other locations where red raspberry plants appeared diseased. However, population estimates of $V$. dahliae quantified from soil samples by the two laboratories were often very inconsistent, ranging from completely absent to $>200$ propagules per gram of soil, leading to confusion as to whether $V$. dahliae was actually present or not. Growers became concerned that $V$. dahliae was a previously undiagnosed problem for the industry and might be responsible for diseased plants in other production fields that could not be attributed to $P$. rubi, $P$. penetrans, or RBDV.

A survey was conducted in 2013 and 2014 to clarify whether $V$. dahliae was widely distributed in the industry and to determine which pathogens were associated with late-summer disease symptoms in Washington red raspberry production fields. Our objectives were to (i) establish the incidence and soil population levels of $V$. dahliae in red raspberry production fields, (ii) compare diagnostic methods and laboratories for detecting and quantifying $V$. dahliae from raspberry field soil (semi-selective agar media versus quantitative polymerase chain reaction [qPCR]), and (iii) assess which pathogens are associated with late-summer disease symptoms of raspberry.

\section{Materials and Methods}

Raspberry field survey design. In 2013 and 2014, 71 sites were sampled from 24 raspberry fields located in Whatcom County, WA. Twenty of the surveyed fields had been planted with the cultivar
Meeker, two fields with Chemainus, and one field each with Saanich and Willamette. Soils were generally classified as silt loams or sandy loams, with Kickerville Silt Loam (26\% of sites) and Lynden Sandy Loam (43\% of sites) predominating. Sites within each field were located at least $61 \mathrm{~m}$ apart and designated as either "healthy" or "disease" types based on the absence or presence of symptoms, respectively. When possible, multiple sites were sampled within each field to include at least one healthy and one disease site (average two disease sites and one healthy site per field). Healthy sites (20 total) were defined as a 6-m length of crop row (8 to 10 plants) in which none of the plants exhibited disease symptoms (Fig. 1A). Plants at these sites were generally dark green in color, with healthy, vigorous primocanes. Disease sites (51 total) were defined as a 6-m length of crop row (8 to 10 plants) with at least five plants exhibiting symptoms characteristic of vascular wilt or root disease (Fig. 1B, C, and D), including chlorosis, scorch, wilting (Fig. 2A), stunting, vascular discoloration, primocane lesions extending 3 to $15 \mathrm{~cm}$ up from root system (Fig. 2B), or cane dieback and plant death. In addition, plants from disease sites tended to have fewer canes per plant than those in healthy sites and there were sometimes empty spaces where plants had died.

Sample collection. Each site was sampled once, in either September 2013 or September 2014, when severe late-summer symptoms were most apparent. From each site, cane, soil, and root samples were collected from three to five plants. A single symptomatic (disease sites) or asymptomatic (healthy sites) cane was collected from each plant. Sites that were more recently planted had smaller plants with fewer canes; therefore, canes were not collected at six sites (three healthy and three disease sites). Each cane was cut at the soil line and then again at $30 \mathrm{~cm}$ above the soil line, resulting in a $30-\mathrm{cm}$ length of stem. All canes from a site were then bulked and placed into a labeled, resealable plastic bag. A volume of soil and roots $\left(6 \mathrm{~cm}^{2}\right.$ by $15 \mathrm{~cm}$ ) was also collected by shovel adjacent to each sampled plant, bulked by site, and placed into separate, labeled, resealable plastic bags. Sites that were more recently planted had smaller plants with smaller root systems. Therefore, roots were not collected at eight sites (two healthy and six disease sites). All samples were placed into coolers and transported back to the laboratory, where they were stored at $5^{\circ} \mathrm{C}$ until processed (within 3 weeks).

Cane processing. The epidermis of each cane was lightly scraped off with a sterile razor blade to look for lesions or vascular streaking extending up from the root system (Fig. 2C). These symptoms were always consistent with canes that were wilted in the field. When a lesion or vascular discoloration was apparent, a 0.5-by-2-cm chip of stem tissue was excised from the lesion margin or discolored area and surface disinfested with a $0.5 \%$ sodium hypochlorite solution ( $1 \mathrm{~min}$ ) followed by $70 \%$ ethanol $(1 \mathrm{~min})$. If no lesion was apparent (e.g., asymptomatic canes or symptomatic canes without a lesion), a 0.5-by-2-cm chip of stem tissue was excised from a similar location on the cane and surface disinfested using the same procedure. After briefly drying in a laminar flow hood, each chip was then aseptically cut into 12 (2014 samples) or 18 (2013 samples) equally sized pieces. Six pieces from each cane were then plated on Petri plates containing $15 \mathrm{ml}$ of NP10 and PARP (pimaricin, ampicillin, rifampicin, pentachloronitrobenzene) (2013 and 2014 samples), and streptomycinamended (50 mg/liter) potato dextrose agar (SPDA) media (2013 samples only). NP10 is a semi-selective medium used for the diagnosis of V. dahliae (Kabir et al. 2004) and PARP is a semi-selective medium used for pythiaceous species (Kannwischer and Mitchell 1978). SPDA medium was used to determine whether other fungal species besides $V$. dahliae were associated with cane lesions. All resulting cultures were identified on the basis of morphology and internal transcribed spacer (ITS) ribosomal DNA sequence as described previously (Kabir et al. 2004; Stewart et al. 2014).

Root and soil processing. For each site, roots ( 1 to $3 \mathrm{~mm}$ in diameter) were separated from the soil, rinsed under running tap water for $5 \mathrm{~min}$, and divided into three subsamples: one 1.5-g subsample for both $V$. dahliae and $P$. rubi qPCR, one 25-g subsample for $P$. penetrans extraction, and one 0.2-g subsample for RBDV enzyme-linked immunosorbent assay (ELISA) analyses. Root subsamples for $P$. penetrans were processed immediately whereas subsamples for 
$V$. dahliae, $P$. rubi, and RBDV were frozen at $-80^{\circ} \mathrm{C}$ until the respective assays were conducted. Soil from each site was divided into three 50-g subsamples: one for $V$. dahliae soil plating, one for both $V$. dahliae and $P$. rubi $\mathrm{qPCR}$, and one for $P$. penetrans extraction. Soil subsamples for $V$. dahliae soil plating and $P$. penetrans were processed immediately, whereas subsamples for $V$. dahliae and $P$. rubi qPCR were frozen at $-80^{\circ} \mathrm{C}$ until the assays were conducted.
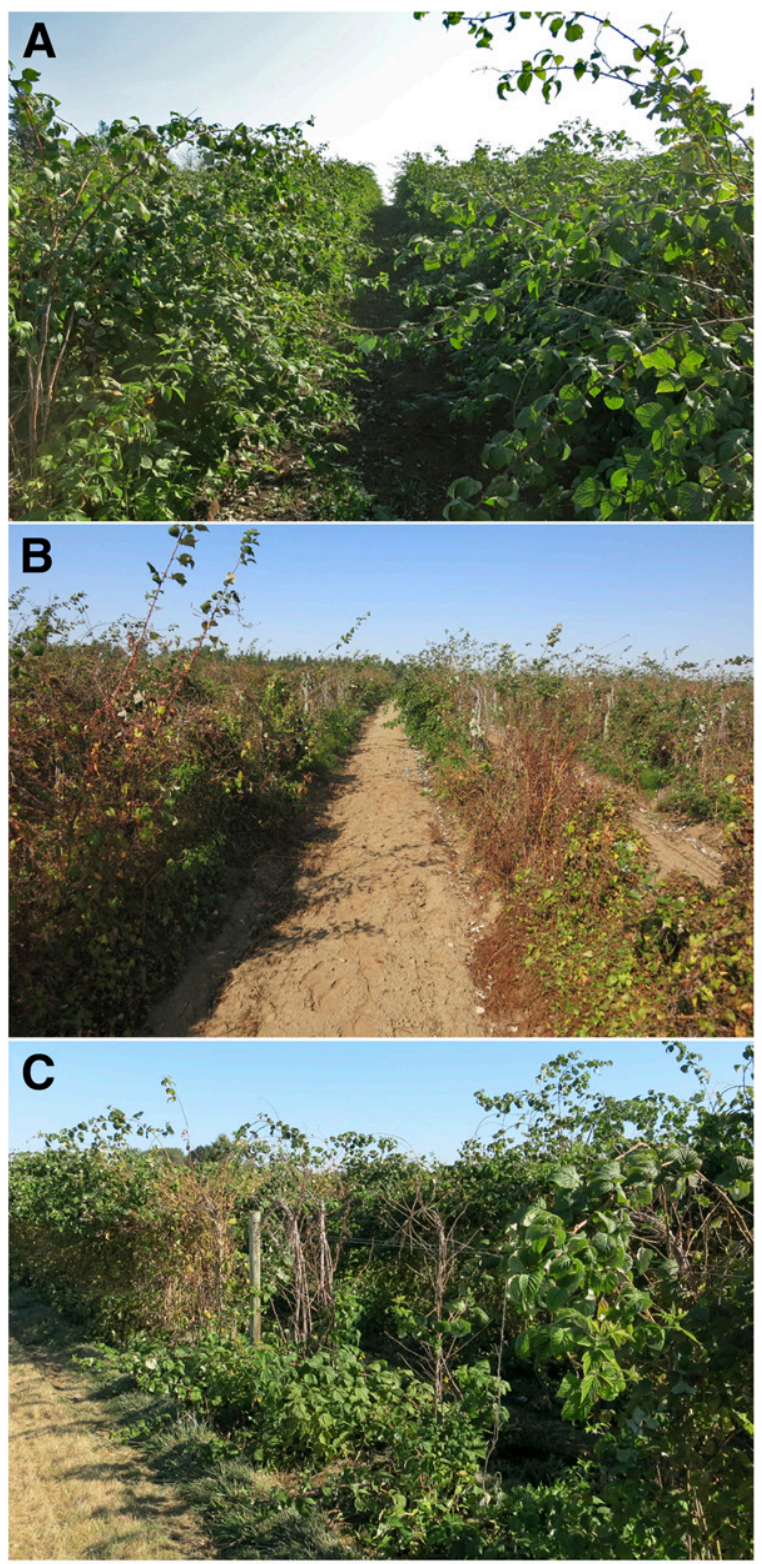

D

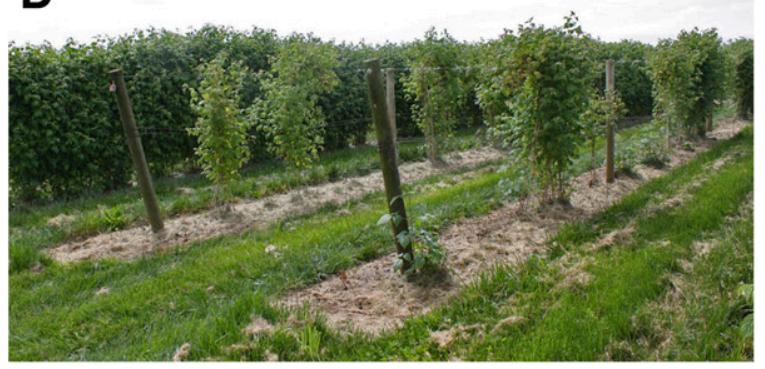

Fig. 1. A, Typical healthy site of red raspberry without symptoms of vascular or root disease. B, Typical disease site with symptoms of stunting, leaf scorch, chlorosis, and wilting on red raspberry. C, Disease site with plants of Meeker red raspberry infected by Verticillium dahliae and showing symptoms of wilting, dieback, and plant death. D, Disease site with plants of Meeker red raspberry exhibiting symptoms of stunting, chlorosis, and plant death. Compare with healthy plants in background.
Soil plating for $\boldsymbol{V}$. dahliae. Each soil subsample was dried for 7 days at $21^{\circ} \mathrm{C}$, sieved through $1-\mathrm{mm}$ mesh, and $1 \mathrm{~g}$ of dried soil was distributed over 20 NP10 plates ( $0.05 \mathrm{~g}$ of soil/plate) using an Anderson sampler (Butterfield and DeVay 1977). Plates were incubated for 2 weeks in the dark at $20^{\circ} \mathrm{C}$ and the number of $V$. dahliae cultures/sample were counted and expressed as propagules per gram (ppg) of dry soil. A similar culture-based assay was not used for $P$. rubi because the pathogen is extremely slow growing and is not easily isolated from soil using semi-selective media.

qPCR for $\boldsymbol{V}$. dahliae and $P$. rubi from roots and soil. For both $V$. dahliae and P. rubi qPCR, total genomic DNA was extracted from root and soil subsamples using a modified protocol from MP FastDNA Spin Kit for Soil Extraction (MP Biomedicals, Santa Ana, CA). A 1-ppg positive control sample of $V$. dahliae was also included to assess extraction efficiency for each set of extractions. After adding sodium phosphate buffer and MT buffer into the lysing matrix tube containing $500 \mathrm{mg}$ of soil or $200 \mathrm{mg}$ of roots, tubes were incubated at $55^{\circ} \mathrm{C}$ for $5 \mathrm{~min}$ to increase cell lysis. Subsamples were then vortexed before homogenization. In the elution step, subsamples were incubated at $55^{\circ} \mathrm{C}$ for $5 \mathrm{~min}$ to increase the release of DNA from the binding matrix. DNA samples were analyzed using qPCR and then stored at $-20^{\circ} \mathrm{C}$ for subsequent analyses. Positive qPCR control samples containing microsclerotia ( $V$. dahliae $)$ at 1,10 , and $100 \mathrm{ppg}$ in sand or $P$. rubi at 2 and $0.002 \mathrm{ng} / \mu \mathrm{l}$ from culture were extracted in advance of unknown soil samples, and DNA aliquots were stored at $-20^{\circ} \mathrm{C}$ until the $\mathrm{qPCR}$ assay was conducted.

The $V$. dahliae qPCR assay was conducted using species-specific primers based on the ribosomal DNA intergenic spacer (IGS) for

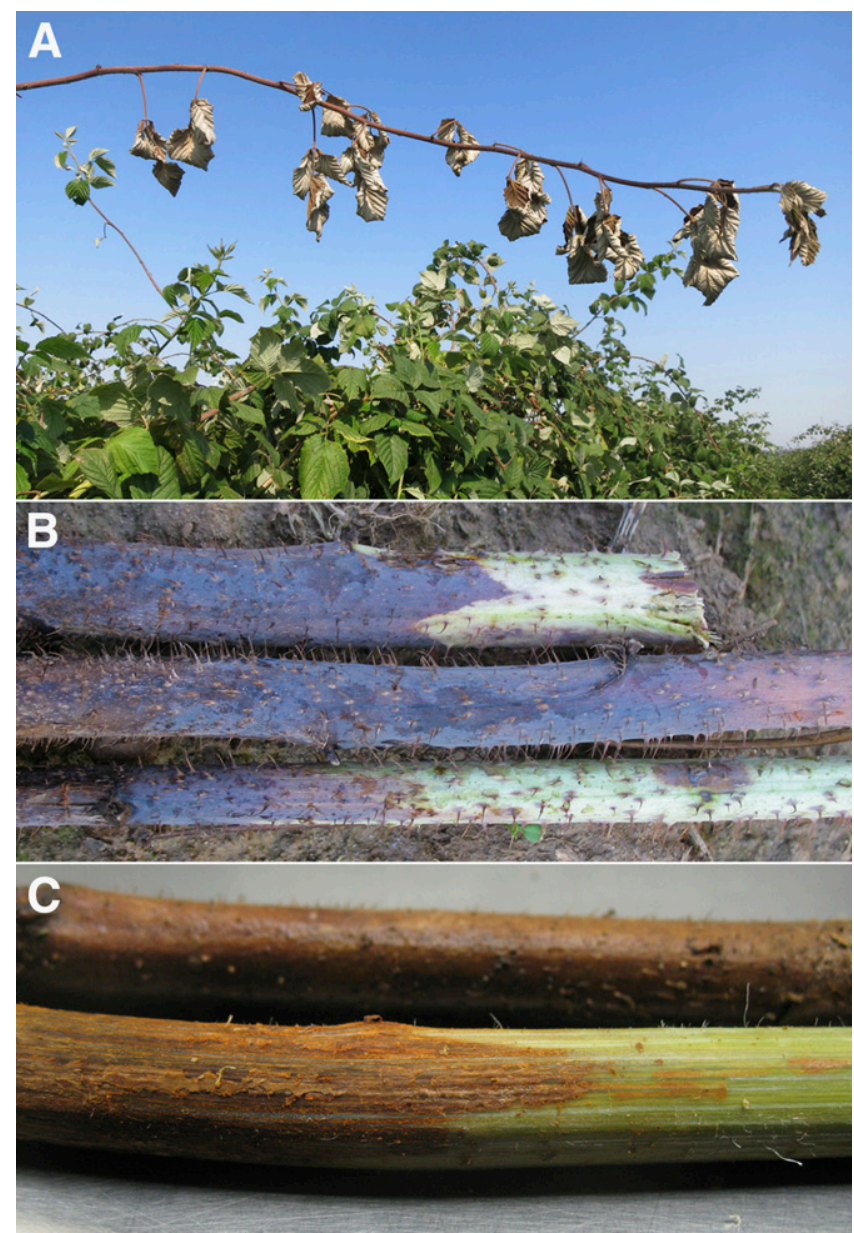

Fig. 2. A, Symptoms of wilt caused by Verticillium dahliae or Phytophthora rubi on a primocane of red raspberry. B, Dark purplish-black lesions typical of $V$. dahliae or $P$. rubi at the base of primocanes of red raspberry cultivar Meeker. C, Reddishblack lesion caused by $P$. rubi underneath the epidermis of Meeker red raspberry. 
$V$. dahliae, which produced a 160-bp product paired with a TaqMan probe labeled with fluorescein (FAM) on the $5^{\prime}$ end and Black Hole Quencher 1 (Biosearch Technologies, Inc., Novato, CA) on the $3^{\prime}$ end (Bilodeau et al. 2012). Each 25- $\mu$ l reaction contained $12 \mu l$ of PerfeCTa qPCR FastMix II, ROX reference dye (Quanta Biosciences, Beverly, MA), $1 \mu \mathrm{M}$ each $V$. dahliae forward and reverse primers, $0.4 \mu \mathrm{M}$ probe, and $4 \mu \mathrm{l}$ of extracted DNA. Twostep PCR conditions were $95^{\circ} \mathrm{C}$ for $2 \mathrm{~min}$, followed by 55 cycles of $95^{\circ} \mathrm{C}$ for $15 \mathrm{~s}$ and $62^{\circ} \mathrm{C}$ for $30 \mathrm{~s}$.

The $P$. rubi qPCR assay was conducted using species-specific primers based on the atp 9 gene for $P$. rubi, which produced a 340-bp product paired with a TaqMan probe labeled with FAM on the $5^{\prime}$ end (Bilodeau et al. 2014) and modified to include a Zen internal quencher (Integrated DNA Technologies, Inc., Coralville, IA) and Iowa Black FQ quencher (Integrated DNA Technologies, Inc.) on the $3^{\prime}$ end. Each $15-\mu 1$ reaction contained $7.5 \mu$ l of PerfeCTa qPCR FastMix II, ROX reference dye (Quanta Biosciences), $0.5 \mu \mathrm{M}$ each P. rubi forward and reverse primers, $0.05 \mu \mathrm{M}$ probe, and $1.5 \mu \mathrm{l}$ of extracted DNA. Two-step PCR conditions were $95^{\circ} \mathrm{C}$ for $2 \mathrm{~min}$, followed by 49 cycles of $94^{\circ} \mathrm{C}$ for $15 \mathrm{~s}$ and $57^{\circ} \mathrm{C}$ for $90 \mathrm{~s}$.

All qPCR samples were performed in triplicate, with each reaction plate containing the appropriate positive reaction controls and template-free controls. DNA amplification data collection and cycle threshold $\left(\mathrm{C}_{\mathrm{T}}\right)$ analysis were conducted using StepOne software (version 2.3; Applied Biosystems, Foster City, CA). For each reaction plate, an automatic baseline was set by the StepOne software and the threshold was manually set to a value of 5,000 for the $V$. dahliae assay and 0.02 for the $P$. rubi assay to allow for plate-to-plate relative comparison and to reduce background fluorescence observed in each assay. The baseline was only manually manipulated when the automatic baseline yielded abnormal amplification curves.

$V$. dahliae and P. rubi DNA quantification was determined for each unknown field subsample by identifying the average $C_{T}$ value for each triplicate reaction where the log-linear phase intercepted the 5,000 and 0.02 threshold value for each of the $V$. dahliae and $P$. rubi assays, respectively. This value was compared with the standard curve described below. Average $\mathrm{C}_{\mathrm{T}}$ values of the known positive controls from each 96-well plate were used to confirm the efficiency of each qPCR plate and to assess the suitability of the standard curve for converting $\mathrm{C}_{\mathrm{T}}$ values to propagule or DNA concentrations.

Quantification of experimental samples was determined by comparing the $\mathrm{C}_{\mathrm{T}}$ value of each unknown soil sample to a standard curve for both $V$. dahliae and $P$. rubi assays. A $V$. dahliae standard curve for soil samples was prepared by diluting microsclerotia generated on cellophane (López-Escudero et al. 2007) into sterile, 0.5-mmdiameter sand at 1,10 , and $100 \mathrm{ppg}$. DNA was extracted using the modified protocol from MP FastDNA Spin Kit for Soil Extraction (described above), and five separate dilution series were analyzed using qPCR as described. The V. dahliae (root) and P. rubi (root and soil) standard curves were developed by doing 10 -fold DNA dilutions using concentrations from $1 \mathrm{ng} / \mu \mathrm{l}$ to $1 \mathrm{fg} / \mu \mathrm{l}$ with the protocols described above. Each standard curve was then generated by averaging the $\mathrm{C}_{\mathrm{T}}$ values for each concentration of either $V$. dahliae or $P$. rubi from the five independent DNA extractions. Amounts of $V$. dahliae detected in the soil were expressed as ppg (for direct comparison with soil plating results), whereas amounts of $V$. dahliae DNA from the roots and $P$. rubi DNA from the soil and roots were expressed as $\mathrm{pg} / \mu \mathrm{l}$.

Comparison of diagnostic laboratories for detection and quantification of $\boldsymbol{V}$. dahliae from soil. In addition to the dry soil plating and qPCR methods described above to detect and quantify $V$. dahliae from soil by our laboratory (Lab 1), representative soil subsamples $(50 \mathrm{~g})$ from six sites, as well as a positive (sample 5, 0.5-mm-diameter sand infested at $100 \mathrm{ppg}$ ) and a negative (sample 7, sterilized 0.5mm-diameter sand without $V$. dahliae) control soil subsample, were sent to three diagnostic laboratories for analysis. Lab 2 used the same dry-plating method described above and distributed air-dried soil over NP10 plates using an Andersen sampler. Lab 3 washed the soil through a series of sieves to concentrate $V$. dahliae microsclerotia, then plated the residue remaining on the $37-\mu \mathrm{m}$ sieve (Martin et al. 1982) onto NP10 (wet-plating method). Lab 4 used a published SYBR Green qPCR method using primers from the ITS region (Lievens et al. 2006). Additional 50-g subsamples from each of the six sites and the positive and negative controls were also tested in our laboratory using an alternative soil plating method, where the soil was first pretreated with $3 \mathrm{ml}$ of methionine solution $(7.5 \mathrm{mg} / \mathrm{ml})$ for 1 week at $30^{\circ} \mathrm{C}$ (Bilodeau et al. 2012) before plating on NP10 with the Anderson sampler according to methods described above. The use of methionine is thought to break microsclerotial dormancy (Kapulnik et al. 1985).

Vegetative compatibility typing of $\boldsymbol{V}$. dahliae. Eight $V$. dahliae isolates (six plant isolates and two soil isolates) from four sites were characterized by vegetative compatibility typing. The vegetative compatibility group (VCG) of each isolate was determined as described by Joaquim and Rowe (1990), but with a few modifications. Nitrate-nonutilizing (nit) mutants were generated by culturing singlespored $V$. dahliae isolates on $2.0 \%$ water agar amended with dextrose $(0.2 \mathrm{~g} / \mathrm{liter})$ and $\mathrm{KClO}_{3}(50 \mathrm{~g} / \mathrm{liter})$. Plates were incubated at room temperature $\left(22\right.$ to $\left.23^{\circ} \mathrm{C}\right)$ for 2 to 4 weeks. Potential nit mutants from

Table 1. Number of sites from which Verticillium dahliae, Phytophthora rubi, Pratylenchus penetrans, and Raspberry bushy dwarf virus (RBDV) were detected from cane, root, or soil samples collected from disease or healthy sites in 24 red raspberry fields in Whatcom County, WA

\begin{tabular}{|c|c|c|c|c|}
\hline \multirow[b]{2}{*}{ Site type } & \multicolumn{4}{|c|}{ Number of pathogen detection sites/total sites $(\%)^{\mathbf{a}}$} \\
\hline & Cane $^{b}$ & $\operatorname{Root}^{\mathbf{c}}$ & Soil (plate) & $\overline{\text { Soil (qPCR, extr., or ELISA) }}{ }^{\mathrm{d}}$ \\
\hline \multicolumn{5}{|l|}{ V. dahliae } \\
\hline Disease & $3 / 48(6)$ & $32 / 45(71)$ & $11 / 51(22)$ & $36 / 48(75)$ \\
\hline Healthy & $0 / 17(0)$ & $12 / 18(67)$ & $4 / 20(20)$ & $15 / 20(75)$ \\
\hline \multicolumn{5}{|l|}{ P. rubi } \\
\hline Disease & $26 / 48(54)$ & $30 / 45$ (67) & $\ldots$ & $31 / 48(65)$ \\
\hline Healthy & 0/17 (0) & 7/18 (39) & $\ldots$ & 3/20 (15) \\
\hline \multicolumn{5}{|c|}{ P. penetrans } \\
\hline Disease & $\ldots$ & 44/45 (98) & $\ldots$ & 43/48 (90) \\
\hline Healthy & $\ldots$ & $14 / 18(78)$ & $\ldots$ & $16 / 20(80)$ \\
\hline \multicolumn{5}{|l|}{ RBDV } \\
\hline Disease & $\ldots$ & $25 / 45(56)$ & $\ldots$ & $\ldots$ \\
\hline Healthy & $\ldots$ & $8 / 18(44)$ & $\ldots$ & $\ldots$ \\
\hline
\end{tabular}


then analyzed by the $\chi^{2}$ test for independence or by Fisher's exact test (for counts $<5$ ) for effects of site type and pathogen. All data analyses were performed using Minitab (version 17.3.1; Minitab, State College, PA).

\section{Results}

V. dahliae. In both 2013 and 2014, V. dahliae was isolated from cane lesions of only six (4\%) symptomatic plants located at three (6\%) disease sites (Table 1; Fig. 1C). Of the six V. dahliae isolates obtained, three were assigned to VCG4B (one isolate from each site), two to VCG2B (one site), and one isolate could not be determined. In all cases, infected plants exhibited symptoms of leaf chlorosis, scorch, and primocane wilting, sometimes with a dark purplishblack lesion at the base of the cane (Fig. 2B). After scraping away the epidermis, a dark purplish- to reddish-black vascular discoloration was visible in the underlying wood tissues. Although plants from the other disease sites exhibited similar symptoms, $V$. dahliae was not isolated from canes at those sites or from asymptomatic, healthy canes collected from healthy sites. Isolation frequency was independent of site type $(P=0.561)$.

In contrast to the cane isolation results, $V$. dahliae was detected much more frequently from the roots using qPCR. The pathogen was detected in roots at $71 \%$ of the disease sites and $67 \%$ of the healthy sites (Table 1). However, similar to the cane isolation results, detection frequency was independent of site type $(P=0.728)$. The amount of $V$. dahliae DNA detected by qPCR from the roots $(\mathrm{pg} / \mu \mathrm{l})$ was also similar from disease sites and healthy sites $(P \geq 0.262)$ (Table 2$)$.

Using the soil plating method, $V$. dahliae was detected from approximately $20 \%$ of both disease and healthy sites (Table 1) and, as observed with cane isolation and root qPCR results, detection frequency was independent of site type $(P=0.884)$. Soil populations ranged from 0 to $645 \mathrm{ppg}$ (Table 2), with most detections falling in the low (1 to $9 \mathrm{ppg}$ ) soil population category (Table 3 ). The one healthy site that registered $645 \mathrm{ppg}$ had been planted in potato previously and two soil isolates from this location were assigned to VCG4B. However, there was no difference in $V$. dahliae population levels between disease and healthy sites $(P=0.795)$ (Table 2).

In contrast to the soil plating results, $V$. dahliae was detected much more frequently from soil using qPCR $(P<0.001)$ and detection frequency was similar to that detected from the roots using qPCR $(P \geq$ 0.572 ). Soil qPCR detected $V$. dahliae in $75 \%$ of both disease and healthy sites (Table 1) and, as with the other detection methods, detection frequency was independent of site type $(P=0.999)$. Soil populations ranged from 0 to $111 \mathrm{ppg}$ (Table 2), with most detections falling in the trace ( $<1 \mathrm{ppg}$ ), low (1 to $9 \mathrm{ppg}$ ), or moderate (10 to
$99 \mathrm{ppg}$ ) soil population categories (Table 3). Soil qPCR detected a similar number of sites with low, moderate, or high soil populations of $V$. dahliae as the soil plating method ( $P \geq 0.080$ ) (Table 3). However, soil qPCR detected a greater number of sites with trace amounts of the pathogen than the plating method $(P \leq 0.001)$. Similar to the soil plating results, the amount of $V$. dahliae detected by qPCR was similar in disease and healthy sites $(P=0.106)$ when the analysis included sites where no $V$. dahliae was detected (e.g., 0s) (Table 2). However, when these sites were removed from the analysis (analysis only included sites where $V$. dahliae was detected), populations of $V$. dahliae were, on average, three times greater at disease sites than from healthy sites $(P=0.014)$ (Table 2$)$.

Laboratories and methods differed in their ability to detect and quantify $V$. dahliae from soil (Table 4), and there was little consistency in population estimates for each particular sample. For example, sample 5 (the positive control sample infested at $100 \mathrm{ppg}$ ) was the only sample from which all four laboratories and all methods were able to detect the pathogen. However, population estimates for this sample varied from a low of 5 ppg with the wet-plating method (Lab 3) to 288 ppg with the qPCR method using ITS primers (Lab 4), and with the most accurate population estimates of 37 and $64 \mathrm{ppg}$ coming from the laboratories using the dry-plating method. Both qPCR methods tended to detect $V$. dahliae more frequently and at higher population levels than those from plating methods. For example, both qPCR methods detected $V$. dahliae in at least five of the eight soil samples and population estimates from samples 1,3 , and 5 were usually greater (12 to $288 \mathrm{ppg}$ ) than those estimated using soil plating methods (0 to $64 \mathrm{ppg})$. Although Lab 3 detected $V$. dahliae in six of the eight soil samples using the wet-plating method, this laboratory was the only facility to detect the pathogen in the negative control (sample 7).

$\boldsymbol{P}$. rubi. In contrast to $V$. dahliae, $P$. rubi was isolated more frequently from cane lesions (Table 1). P. rubi was isolated from 43 (27\%) of the symptomatic plants located at $54 \%$ of the disease sites. Symptoms of plants infected by $P$. rubi were very similar to those observed for $V$. dahliae, including the presence of a purplish-black lesion extending up from the roots at the base of the cane (Fig. 2B). However, in contrast to stems infected by $V$. dahliae, the underlying tissue was more often discolored reddish-black (Fig. 2C) rather than a dark purplish-black, although this symptom was not always consistent. Isolation frequency differed between site types $(P<0.001)$, with all $P$. rubi cane isolations occurring only from disease sites and not healthy sites. The pathogen was never isolated from asymptomatic, healthy canes.

Using qPCR, $P$. rubi was detected more frequently in the roots and soil from disease sites (67 and 65\%, respectively) than from healthy

Table 2. (Continued from previous page)

\begin{tabular}{|c|c|c|c|c|}
\hline \multirow[b]{2}{*}{ Site type } & \multicolumn{2}{|c|}{ P. rubi } & \multicolumn{2}{|c|}{ P. penetrans } \\
\hline & Root qPCR $(\mathrm{pg} / \mu \mathrm{l})^{\mathrm{b}}$ & Soil qPCR $(\mathrm{pg} / \mu \mathrm{l})^{\mathrm{c}}$ & Nematodes/g of root ${ }^{b}$ & Nematodes/100 $\mathrm{g}$ of soil ${ }^{\mathrm{c}}$ \\
\hline \multicolumn{5}{|c|}{ Includes $0 \mathrm{~s}^{\mathrm{d}}$} \\
\hline Disease & $9.520 \pm 5.800(0-218.010) n=45$ & $0.268 \pm 0.139(0-5.861) n=48$ & $1,362 \pm 309(0-8688) n=45$ & $65 \pm 13(0-415) n=48$ \\
\hline Healthy & $0.089 \pm 0.061(0-1.015) n=18$ & $0.026 \pm 0.019(0-0.380) n=20$ & $1,356 \pm 470(0-5492) n=18$ & $54 \pm 13(0-202) n=20$ \\
\hline$P={ }^{\mathrm{e}}$ & 0.009 & 0.002 & 0.398 & 0.909 \\
\hline \multicolumn{5}{|c|}{ Excludes $0 \mathrm{~s}^{\mathrm{f}}$} \\
\hline Disease & $14.280 \pm 8.610(0.010-218.010) n=30$ & $0.414 \pm 0.211(0.003-5.861) n=31$ & $1,393 \pm 315(10-8688) n=44$ & $72 \pm 14(1-415) n=43$ \\
\hline Healthy & $0.252 \pm 0.158(0.007-1.015) n=7$ & $0.174 \pm 0.103(0.061-0.380) n=3$ & $1,743 \pm 565(30-5492) n=14$ & $67 \pm 15(1-202) n=16$ \\
\hline$P={ }^{\mathrm{e}}$ & n.a. & n.a. & 0.643 & 0.523 \\
\hline
\end{tabular}


sites (39 and $15 \%$, respectively) $(P \leq 0.044)$ (Table 1$)$. Similarly, the amount of $P$. rubi DNA detected in both the roots and soil from disease sites was greater than that from healthy sites $(P \leq 0.009)$ (Table 2$)$.

Other fungal genera. The genera Alternaria and Fusarium were also frequently isolated from cane lesions on symptomatic plants sampled from disease sites in 2013 (33 and 43\% of plants, respectively). Preliminary isolate identification, based on morphology and $99 \%$ sequence identity with the ITS sequence, indicated that the most commonly encountered species were Alternaria alternata, A. brassicae, Fusarium avenaceum, and $F$. tricinctum (data not shown). Subsequent stem (colonized agar plug) and root (infested soil at 10,000 ppg) inoculations of Meeker red raspberry with a representative isolate of each pathogen did not result in disease (data not shown). Therefore, no further attempts were made to identify or detect these species in 2014.

$P$. penetrans and RBDV. $P$. penetrans was recovered more frequently from roots at disease sites $(98 \%)$ than from healthy sites (78\%) $(P=0.021)$ (Table 1). However, the frequency of P. penetrans recovered from soil at disease sites $(90 \%)$ was similar to that at healthy sites $(80 \%)(P=0.288)$. There was no difference between the two site types in the population density of $P$. penetrans recovered from either the roots $(P \geq 0.398)$ or the soil $(P \geq 0.523)$ (Table 2$)$. RBDV frequency was also independent of site type $(P=0.425)$, and the virus was just as likely to be found in disease sites (56\%) as in healthy sites $(44 \%)$

Co-occurrence of pathogens. When the results of all detection methods for all four pathogens were combined, most sites (68 of 71 sites, or 96\%) had at least one pathogen detected (Table 5). This corresponded to V. dahliae being detected in 21 of 24 (88\%), P. rubi in 19 of $24(79 \%)$, P. penetrans in 20 of $22(91 \%)$, and RBDV in 10 of 19 $(53 \%)$ of the 24 production fields. Only three sites (one disease and two healthy sites) had no pathogens detected. Regardless of detection method, $V$. dahliae, $P$. penetrans, and RBDV were detected with similar frequency from disease and healthy sites (Fig. 3). P. rubi, on the other hand, was over twice as likely to be detected from disease sites as from healthy sites (Fig. 3). Because of the relatively high incidence of each pathogen during the survey, most sites had at least two, three, or all four pathogens present (Table 5). However, there was no difference between disease and healthy sites for the co-occurrence of most pathogens, except for the specific combination of $V$. dahliae, $P$. rubi, and $P$. penetrans, or for all four pathogens combined (Table 5). The detection frequency of these two specific pathogen combinations was similar $(P=0.171)$ and, when taken together, V. dahliae, $P$. rubi, and $P$. penetrans, either with or without RBDV, were much more prevalent at disease sites than healthy sites $(P \leq 0.003)$ (Fig. 3). Co-infection by $V$. dahliae and P. rubi was confirmed from one plant where both pathogens were isolated from the same cane lesion.

\section{Discussion}

This survey is important for establishing the incidence and cooccurrence of $V$. dahliae, P. rubi, P. penetrans, and RBDV in the red raspberry industry of northern Washington and for determining their association with vascular and root disease symptoms in late summer. Previous research indicated that $P$. rubi, $P$. penetrans, and RBDV were common in red raspberry (Gigot et al. 2013; Martin 1998), but this is the first time that the incidence of $V$. dahliae, as well as all four pathogens together, has been evaluated for this crop. Based on our survey, $V$. dahliae is widespread in most production fields and is just as likely to be found in disease sites as healthy sites. However, $V$. dahliae soil populations were slightly greater, on average, from disease sites and the pathogen was occasionally isolated from the canes of diseased plants, indicating that there is some potential for it to cause disease. Our survey also confirms that $P$. rubi, $P$. penetrans, and RBDV continue to be widespread in the industry. However, in contrast to $V$. dahliae, $P$. rubi was repeatedly isolated from the canes of diseased plants, and the pathogen was consistently detected more frequently, and in greater amounts, from disease sites than healthy sites. $P$. penetrans, on the other hand, was more frequently detected from the roots, but not soil, at disease sites even though root and soil nematode populations were similar across both site types. RBDV was encountered less frequently than the three soilborne pathogens and was no more likely to be detected at sites with late-summer disease symptoms than from healthy sites. Regardless of RBDV presence, disease sites were more likely to have all three soilborne pathogens present than healthy sites, indicating that a soilborne disease complex may be an important limitation for raspberry production. However, of the three soilborne pathogens, $P$. rubi was most consistently associated with disease sites and was the most frequently isolated pathogen from cane lesions on severely diseased (wilting) plants. These results suggest that $P$. rubi is probably the primary pathogen driving disease in late summer, but higher soil populations of $V$. dahliae and root infection by $P$. penetrans are also likely to play a role.

$V$. dahliae has been known as a pathogen of red raspberry since it was first discovered over 100 years ago infecting the variety Antwerp in western Washington (Lawrence 1912). Despite occasional outbreaks in the past (Berkeley and Jackson 1926; Harris 1928; Zeller 1936), V. dahliae seems to rarely cause economically significant disease in newer red raspberry varieties in North America (Koike et al. 2015) (M. Bolda, G. Fernandez, K. Ivors, S. Koike, S. Sabaratnam, A. Schilder, and W. Wilcox, personal communication), especially in comparison with black raspberry varieties (Fiola and Swartz 1994; Mercier and Kong 2017; Zeller 1936). Greenhouse inoculations of the red raspberry variety Meeker with $V$. dahliae isolates obtained during this survey often resulted in the same types of symptoms that were observed during our survey, including chlorosis, leaf scorch, stunting, wilting, vascular discoloration and cane lesions, and cane dieback (J. Weiland, unpublished data). Yet, most plants were not killed by the pathogen ( 35 of 39 plants, $90 \%$ survival) and were able to produce new primocanes that appeared healthy. Our survey results support these observations and indicate that $V$. dahliae is infrequently associated with severe disease in the field. However, we consistently detected $V$. dahliae in the roots of field-grown plants with qPCR, which suggests that root infection is common. It may be that the host is able to limit pathogen colonization or that field conditions are not favorable for the development of severe disease symptoms when caused by $V$. dahliae alone. The pathogen may also be causing sublethal effects that reduce raspberry health over the lifespan of the crop. It is also unknown whether $V$. dahliae and $P$. penetrans interact to produce more severe disease in raspberry as they do in other disease complexes such as potato early dying (Martin et al. 1982). In our survey, there were 12 sites where both $V$. dahliae and $P$. penetrans were detected without the potential confounding presence of $P$. rubi (Table 5, VN + VNR). Of these, 8 sites were characterized as healthy ( 8 of $20,40 \%)$, whereas only 4 sites were characterized as diseased $(4$ of $51,8 \%$ ). This suggests that the presence of both $V$. dahliae and $P$. penetrans is not associated with increased disease. However, there were too few sites that met this condition to make a firm conclusion. Additional studies are warranted to determine whether there are long-term impacts of root infection by $V$. dahliae on either the yield or longevity of red raspberry plantings, or if $V$. dahliae interacts with $P$. penetrans to cause more severe disease in red raspberry.

Of the $V$. dahliae isolates obtained from raspberry plants and field soil, five were VCG4B (from four sites) and two were VCG2B (from a single site). To our knowledge, there is only one other report where a $V$. dahliae isolate from red raspberry was assigned to a VCG, and that was for a single isolate from Washington assigned to VCG4A (Dung et al. 2013). Previous studies show that certain VCG subgroups are more common or aggressive on specific hosts (Dung et al. 2013; Joaquim and Rowe 1991). For example, VCG4A and VCG4B are common on potato and VCG2B is a common, aggressive pathogen of mint (Dung et al. 2013). However, cross pathogenicity may occur and VCGs of one subgroup may infect other hosts. Currently, there are too few $V$. dahliae isolates from red raspberry that have been characterized to VCG to conclude whether any one VCG predominates on this host. Nevertheless, this information may be useful for future breeding efforts to evaluate resistance to V. dahliae in Rubus spp. crosses. In Whatcom County, where the current survey was conducted, potato is occasionally grown as a rotation 
crop with red raspberry. This may explain why VCG4B occurred at four sites.

Growers have expressed considerable frustration in trying to interpret contradictory lab reports about the presence of $V$. dahliae in their field soils. Earlier research indicated that there was considerable variability in estimating soil $V$. dahliae populations depending on the laboratory and method used (Termorshuizen et al. 1998). Our results show that this is still the case, despite advancements in pathogen detection and quantification using qPCR technology. However, each method has advantages and disadvantages. Compared with the dryplating method, the wet-plating method may lower the detection limit by concentrating microsclerotia from a larger soil volume on a sieve. However, this method is less accurate than dry-plating methods (Termorshuizen et al. 1998) and, in our study, the wet-plating method had the lowest population estimate $(5 \mathrm{ppg})$ for the positive control soil sample infested at $100 \mathrm{ppg}$ (sample 5). We were also surprised that the laboratory using this method detected $V$. dahliae in the negative control soil sample (sample 7) and later discovered that this was likely due to inoculum carryover on an incompletely decontaminated sieve. Thus, the other results from this laboratory are suspect. For the dry-plating method, estimates of $V$. dahliae may be lower than the actual soil population because some microsclerotia may be nonviable

Table 3. Number of sites (both disease and healthy) in 24 red raspberry fields in Whatcom County, WA from which Verticillium dahliae was detected in each of five soil population categories

\begin{tabular}{lcc}
\hline Soil population category $(\mathbf{p p g})^{\mathbf{a}}$ & Plating & $\mathbf{q P C R}^{\mathbf{b}}$ \\
\hline None $(0)$ & 56 & 17 \\
Trace $(<1)$ & 0 & 35 \\
Low (1-9) & 13 & 9 \\
Mod. (10-99) & 1 & 6 \\
High ( $\geq 100)$ & 1 & 1 \\
\hline
\end{tabular}

a Soil population categories based on the number of $V$. dahliae propagules detected per gram (ppg) of dry soil.

${ }^{\mathrm{b}}$ Quantitative polymerase chain reaction.

Table 4. Estimates of Verticillium dahliae soil populations from eight soil samples taken from red raspberry fields in Whatcom County, WA and processed using different detection methods at different laboratories

\begin{tabular}{|c|c|c|c|c|c|c|}
\hline \multirow[b]{4}{*}{ Sample $^{\mathrm{c}}$} & \multicolumn{6}{|c|}{ Estimated $V$. dahliae soil population (ppg) } \\
\hline & \multicolumn{4}{|c|}{ Soil platinga } & \multicolumn{2}{|c|}{$\mathbf{q P C R}$} \\
\hline & DP & DP & DP+M & WP & ITS & IGS \\
\hline & $\overline{\text { Lab } 1}$ & $\overline{\text { Lab } 2}$ & $\overline{\text { Lab } 1}$ & $\overline{\text { Lab } 3}$ & $\overline{\text { Lab } 4}$ & $\overline{\text { Lab } 1}$ \\
\hline Sample 1 & 0 & 2 & 1 & 0 & 216 & 12 \\
\hline Sample 2 & 0 & 0 & 0 & 3 & 4 & 0 \\
\hline Sample 3 & 2 & 0 & 1 & 1 & 275 & 186 \\
\hline Sample 4 & 0 & 0 & 0 & 2 & 2 & 0 \\
\hline Sample 5 (PC) & 64 & 37 & 10 & 5 & 288 & 33 \\
\hline Sample 6 & 0 & 0 & 1 & 4 & 5 & 1 \\
\hline Sample 7 (NC) & 0 & 0 & 0 & 1 & 0 & 0 \\
\hline Sample 8 & 1 & 0 & 0 & 0 & 0 & 1 \\
\hline Total + samples & 3 & 2 & 4 & 6 & 6 & 5 \\
\hline Average & 10 & 6 & 2 & 2 & 113 & 33 \\
\hline
\end{tabular}

a Soil plating methods: DP = soil was dry sieved and plated onto NP10 medium (Kabir et al. 2004) using an Andersen sampler (Butterfield and DeVay 1977); DP+M = soil was dry sieved, pretreated with methionine, and plated onto NP10 media using an Andersen sampler (Bilodeau et al. 2012); and WP = soil was wet sieved and wet plated onto NP10 media (Martin et al. 1982).

${ }^{\mathrm{b}}$ Quantitative polymerase chain reaction (qPCR) methods: ITS $=$ SYBR Green qPCR based on $V$. dahliae-specific internal transcribed spacer (ITS) primers (Lievens et al. 2006) and intergenic spacer (IGS) = TaqMan qPCR assay based on $V$. dahliae-specific IGS primers (Bilodeau et al. 2012).

${ }^{c} \mathrm{PC}=$ positive control, 0.5 -mm-diameter sand infested with $V$. dahliae at 100 propagules per gram (ppg); $\mathrm{NC}=$ negative control, sterilized 0.5 -mm-diameter sand without $V$. dahliae; Total = total number of samples from which $V$. dahliae was detected; and Average $=$ average soil population of $V$. dahliae detected by method and laboratory, excluding negative control. or dormant, and the growth of other, competing fungal species on the NP10 medium may obscure detection or inhibit the formation of $V$. dahliae colonies. In addition, this method has a detection limit of $1 \mathrm{ppg}$ when $0.05 \mathrm{~g}$ of soil are distributed onto 20 plates of NP10. Although the detection limit could be lowered by increasing the amount of soil per plate, we have found that this often reduces $V$. dahliae counts due to increased competition from other fungi. It would also be too time consuming and resource intensive to lower the detection limit by increasing the number of plates; 200 plates would need to be prepared and analyzed to reduce the detection limit to $0.1 \mathrm{ppg}$. Adding methionine did not significantly increase detection and, instead, seemed to reduce $V$. dahliae counts from soil infested at higher inoculum levels in this study (sample 5), as well as from naturally infested field soils in previous tests by our laboratory (data not shown).

In contrast to the plating methods, the two qPCR methods were much more sensitive at detecting the presence of $V$. dahliae, but sometimes overestimated $V$. dahliae soil populations. This could be due to the presence of dormant or dead microsclerotia and hyphae, which would yield $V$. dahliae DNA, but would not produce colonies on NP10 media. Alternatively, this may be due to the presence of large, multicellular microsclerotia, a single one of which would release more $V$. dahliae DNA that would artificially inflate population estimates, but would only yield a single colony on a plate. There is also a possibility that the qPCR method used by Lab 4 is not specific to $V$. dahliae. The ITS primers for this method (Lievens et al. 2006) were developed before the description of five new Verticillium spp. in 2011 (Inderbitzin et al. 2011) and, therefore, might be amplifying one of the new species or the closely related hybrid, $V$. longisporum, of which some lineages share an ITS sequence with $V$. dahliae (Inderbitzin et al. 2013). This would mistakenly inflate $V$. dahliae population estimates for this method. IGS primers for $V$. dahliae used in qPCR by our laboratory (Lab 1) have been tested against isolates of all 10 Verticillium species and have been found to be specific to $V$. dahliae (data not shown). Finally, both the ITS and IGS regions are multicopy, which may account for some of the increase in the final $V$. dahliae soil population estimates when using qPCR. Bilodeau et al. (2012) estimated that there are 24 to 73 IGS copies per haploid genome of $V$. dahliae, depending on the isolate, but expected that this would only change the final $C_{T}$ value by $1.8 \mathrm{C}_{\mathrm{T}}$.

Given the different limitations of the methods we evaluated, the dry-plating method may be more accurate for quantifying viable

Table 5. Number and percentage of sites in 24 red raspberry production fields in Whatcom County, WA from which each combination of pathogens was detected

\begin{tabular}{lcc}
\hline & \multicolumn{2}{c}{ Number (\%) } \\
\cline { 2 - 3 } Pathogen combinations detected & Disease sites & Healthy sites \\
\hline None & $1(2)$ & $2(10)$ \\
Verticillium dahliae (V) only & $1(2)$ & $1(5)$ \\
Phytophthora rubi (P) only & $0(0)$ & $0(0)$ \\
Pratylenchus penetrans (N) only & $0(0)$ & $0(0)$ \\
Raspberry bushy dwarf virus (R) only & $0(0)$ & $0(0)$ \\
VP & $2(4)$ & $0(0)$ \\
VN & $3(6)$ & $4(20)$ \\
VR & $0(0)$ & $1(5)$ \\
PN & $3(6)$ & $0(0)$ \\
PR & $0(0)$ & $0(0)$ \\
NR & $1(2)$ & $0(0)$ \\
PNR & $2(4)$ & $1(5)$ \\
VPR & $0(0)$ & $0(0)$ \\
VNR & $1(2)$ & $4(20)$ \\
VPN & $16(31)$ & $5(25)$ \\
VPNR & $21(41)$ & $2(10)$ \\
Total sites & $51(100)$ & $20(100)$ \\
\hline
\end{tabular}

${ }^{a}$ Sites were characterized as diseased (51 sites) or healthy (20 sites) based on the presence or absence of root and vascular disease symptoms in September 2013 and 2014. 
$V$. dahliae from the soil than qPCR when inoculum levels $\geq 1 \mathrm{ppg}$. Caution should be used when interpreting qPCR values associated with $<1 \mathrm{ppg}$. Although it is possible that qPCR could detect less than one microsclerotium per gram of soil, it may be more likely that DNA extraction from a single propagule is not $100 \%$ efficient and that there would be some inherent error in estimating soil populations in terms of propagules per gram based on results from DNA amplification. Finally, the presence of PCR inhibitors in the soil must be taken into account when using qPCR. Initially, Lab 4 did not detect $V$. dahliae from any of the eight soil samples. After discussing the issue with the laboratory, they discovered that their DNA extraction methods did not effectively remove PCR inhibitors and reran the samples after modifying their method to improve inhibitor removal (Table 4). No matter which method is used, considerable care must be taken to ensure that proper controls (both positive and negative) are used and that equipment and materials are thoroughly decontaminated

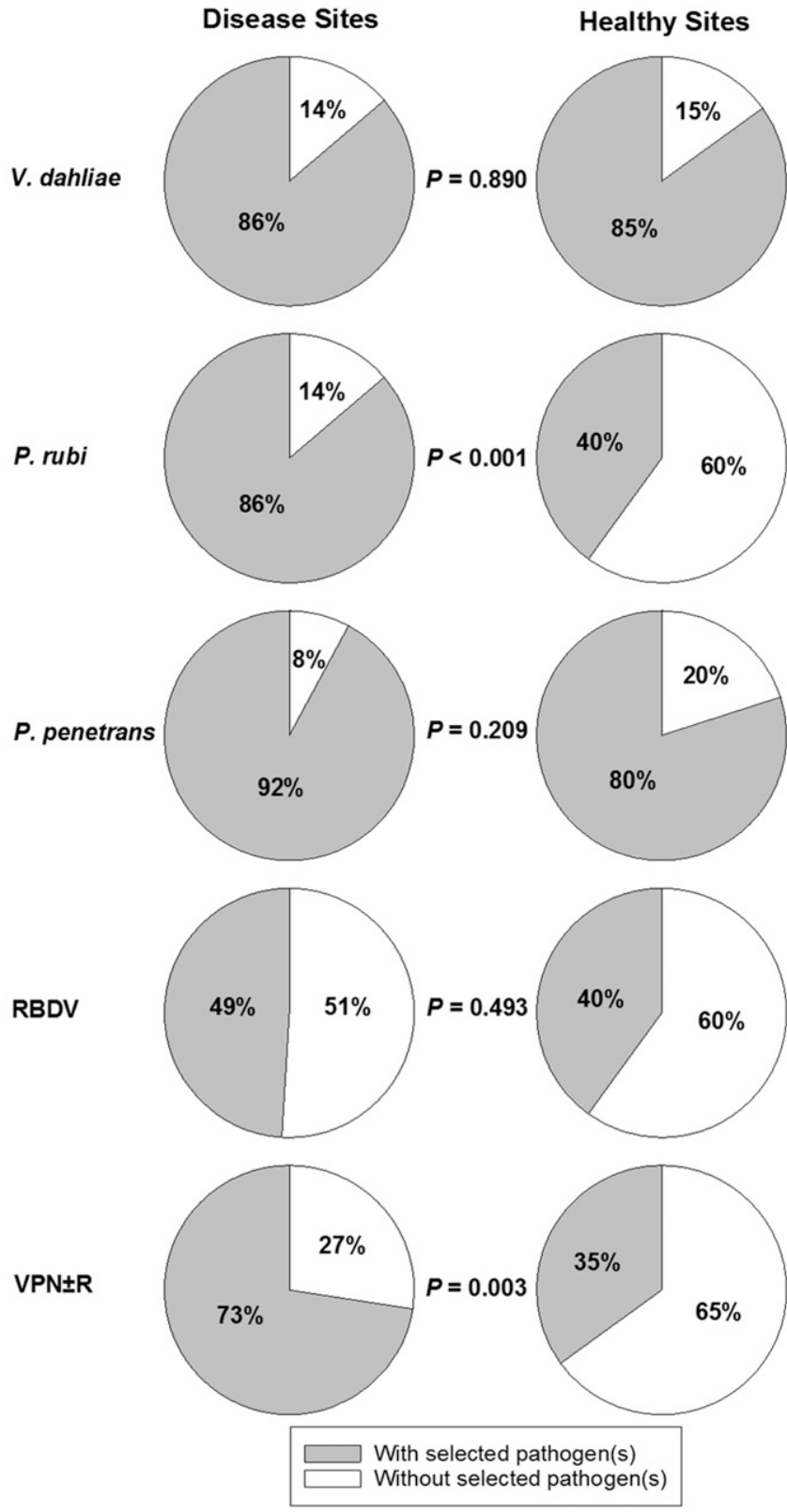

Fig. 3. Percentage of disease sites and healthy sites in red raspberry fields in Whatcom County, WA with Verticillium dahliae, Phytophthora rubi, Pratylenchus penetrans, and Raspberry bushy dwarf virus (RBDV). VPN $\pm R=$ co-occurrence of $V$. dahliae, $P$. rubi, and $P$. penetrans, either with or without RBDV. The frequency of sites for the presence or absence of each selected pathogen or group of pathogens $\left(\mathrm{VPN} \pm \mathrm{R}\right.$ ) was analyzed by the $\chi^{2}$ test for independence or Fisher's exact test (for counts $<5)$ for effect of site type. or sterilized before processing the next sample. Efforts also need to be made to help growers understand the sometimes contradictory and variable $V$. dahliae results from different laboratories depending on the methods used for detection.

It was surprising that we were able to consistently isolate $P$. rubi from the canes of diseased plants in late summer, particularly from plants located in drier fields where $P$. rubi was not known to be a problem and during the time of year when temperatures are warm and rainfall is less abundant. $P$. rubi is considered a cool-weather pathogen, with most activity and infection occurring from November to March in waterlogged soils (Duncan et al. 1991; Wilcox and Cooke 2017; Wilcox et al. 1993). Isolation success is also greatest during that time of year (Wilcox et al. 1993). Damage by the pathogen is reportedly more severe earlier in the growing season as the new primocanes emerge in March to April and as the fruit begins to set in June, but symptoms are also known to occur in summer (Wilcox and Cooke 2017). Our survey confirms that the pathogen is still active and capable of causing disease symptoms in late summer. Although we sampled canes in late summer when isolation success is lower, we were able to consistently isolate the pathogen from $27 \%$ of the symptomatic plants at $54 \%$ of the disease sites using the methods described. Using qPCR allowed us to detect $P$. rubi from a larger number of sites and from the soil and roots, substrates from which the pathogen is more difficult to isolate due to its slow growth and competition from competing organisms (Stewart et al. 2014). We expect that the chances of successfully isolating the pathogen would have been greater during March to June, when we are typically able to isolate $P$. rubi from 60 to $90 \%$ of the symptomatic plants at known Phytophthora root rot sites. Our survey also showed that $P$. rubi is commonly encountered in drier field sites where the pathogen was not expected to be found. This indicates that $P$. rubi is not just a problem in poorly drained, heavy soils or in low-lying areas and confirms previous reports indicating that the pathogen is widespread in the raspberry industry (Gigot et al. 2013).

Our survey shows that $V$. dahliae, $P$. penetrans, and especially $P$. rubi are important components of vascular and root disease in red raspberry production fields of northern Washington, and may form part of a soilborne disease complex (Rudolph and DeVetter 2015; Schilder and Gillett 2007; Weber and Entrop 2017; You et al. 2006) responsible for some of the loss in productivity and longevity of raspberry plantings in northern Washington as well as poor growth in newly replanted fields. The presence of each of these pathogens in $\geq 79 \%$ of production fields and their consistent association with disease sites suggests that current disease control practices are inadequate for reducing population densities of these pathogens and mitigating their associated impacts on plant productivity. Other studies have shown that the fumigant 1,3-dichloropropene may be insufficient to adequately control soilborne fungal and oomycete pathogens, particularly when the fumigated soil is left untarped (Cabrera et al. 2015; Jhala et al. 2012). Currently, most growers do not tarp fields immediately after fumigation, which may allow the fumigants to escape before they have had time to be effective (Walters et al. 2017). In addition, the large woody plant debris left in the field after the previous raspberry crop is killed may serve as "chimneys", allowing fumigants to more easily escape and leave reservoirs of inoculum that could serve to infect the next crop of raspberry (Rudolph and DeVetter 2015). Increased levels of chloropicrin and tarping may be needed to improve efficacy against soilborne fungal and oomycete pathogens, including $P$. rubi and $V$. dahliae. Recent studies with Telone C-35 or Pic-Clor 60 (40\% 1,3-dichloropropene $+60 \%$ chloropicrin) were effective against several fungal and oomycete pathogens when applied under totally impermeable film (Cabrera et al. 2015; Weiland et al. 2016). Improved sanitation before fumigation may also limit pathogen survival in crop debris and decrease the potential for soil reinfestation after fumigation.

Our research goes above and beyond previous surveys in evaluating the presence of multiple pathogens in red raspberry production fields. Both $P$. rubi and P. penetrans are widely distributed in the region. However, based on our extensive survey which evaluated canes, roots, and soil, it appears that $P$. rubi is the pathogen most 
strongly associated with severe, late-summer disease symptoms in red raspberry. This is the first report of the presence and distribution of $V$. dahliae in red raspberry in this region and our findings indicate that, although it is found in many fields, it does not appear to be a primary determinant of severe disease. However, it is possible that the high prevalence of $P$. rubi, which mainly defines the distinction between disease and healthy sites, could be masking less severe symptoms caused by $V$. dahliae and $P$. penetrans. Management of these soil-inhabiting organisms should be tailored to the pathogens present. For example, if a field is at risk from $P$. rubi, then a tarped preplant fumigant with a greater percentage of chloropicrin should be used. Due to the widespread distribution and different biology of $V$. dahliae, $P$. rubi, and $P$. penetrans in Washington red raspberry fields, an integrated management approach, including broad-spectrum disease control measures such as fumigation, will be needed to effectively control these soilborne pathogens.

\section{Acknowledgments}

We thank M. Kitner and J. Scott for their excellent technical support.

\section{Literature Cited}

Ayoub, S. M. 1980. Plant Nematology, An Agricultural Training Aid. NemaAid Publications, Sacramento, CA.

Berkeley, G. H., and Jackson, A. B. 1926. Verticillium wilt of the red raspberry. Sci. Agric. 6:261-270.

Bilodeau, G. J., Koike, S. T., Uribe, P., and Martin, F. N. 2012. Development of an assay for rapid detection and quantification of Verticillium dahliae in soil. Phytopathology 102:331-343.

Bilodeau, G. J., Martin, F. N., Coffey, M. D., and Blomquist, C. L. 2014. Development of a multiplex assay for genus- and species-specific detection of Phytophthora based on differences in mitochondrial gene order. Phytopathology 104:733-748

Butterfield, E. J., and DeVay, J. E. 1977. Reassessment of soil assays for Verticillium dahliae. Phytopathology 67:1073-1078.

Cabrera, J. A., Hanson, B. D., Gerik, J. S., Gao, S. D., Qin, R. J., and Wang, D. 2015. Pre-plant soil fumigation with reduced rates under low permeability films for nursery production, orchard and vineyard replanting. Crop Prot. 75:34-39.

Castillo, P., and Vovlas, N. 2007. Pratylenchus (Nematoda: Pratylenchidae). Diagnosis, Biology, Pathogenicity and Management. Nematology Monographs \& Perspectives, Leiden, The Netherlands.

Duncan, J. M., and Kennedy, D. M. 1989. The effect of waterlogging on Phytophthora root rot of red raspberry. Plant Pathol. 38:161-168.

Duncan, J. M., Kennedy, D. M., and Scott, P. H. 1991. Relationships between non-papillate, soilborne species of Phytophthora root rot of raspberry. Pages 129-147 in: Phytophthora. British Mycological Society Symposia, Vol. 17. A. Lucas, R. Shattock, D. Shaw, and L. Cooke, eds. Cambridge University Press, Cambridge, U.K.

Dung, J. K. S., Peever, T. L., and Johnson, D. A. 2013. Verticillium dahliae populations from mint and potato are genetically divergent with predominant haplotypes. Phytopathology 103:445-459.

Fiola, J. A., and Swartz, H. J. 1994. Inheritance of tolerance to Verticillium alboatrum in raspberry. HortScience 29:1071-1073.

Gigot, J., Walters, T. W., and Zasada, I. A. 2013. Impact and occurrence of Phytophthora rubi and Pratylenchus penetrans in commercial red raspberry (Rubus ideaus) fields in northwestern Washington. Int. J. Fruit Sci. 13:357-372.

Harris, R. V. 1928. The blue stripe wilt of raspberry. J. Pomol. Hortic. Sci. 4:221-229.

Inderbitzin, P., Bostock, R. M., Davis, R. M., Usami, T., Platt, H. W., and Subbarao, K. V. 2011. Phylogenetics and taxonomy of the fungal vascular wilt pathogen Verticillium, with the descriptions of five new species. PLoS One 6:e28341.

Inderbitzin, P., Davis, R. M., Bostock, R. M., and Subbarao, K. V. 2013. Identification and differentiation of Verticillium species and V. longisporum lineages by simplex and multiplex PCR assays. PLoS One 8:e65990.

Jhala, A. J., Gao, S., Gerik, J. S., Qin, R., and Hanson, B. D. 2012. Effects of surface treatments and application shanks on nematode, pathogen and weed control with 1,3-dichloropropene. Pest Manage. Sci. 68:225-230.

Joaquim, T. R., and Rowe, R. C. 1990. Reassessment of vegetative compatibility relationships among strains of Verticillium dahliae using nitrate-nonutilizing mutants. Phytopathology 80:1160-1166.

Joaquim, T. R., and Rowe, R. C. 1991. Vegetative compatibility and virulence of strains of Verticillium dahliae from soil and potato plants. Phytopathology 81: $552-558$

Kabir, Z., Bhat, R. G., and Subbarao, K. V. 2004. Comparison of media for recovery of Verticillium dahliae from soil. Plant Dis. 88:49-55.

Kannwischer, M. E., and Mitchell, D. J. 1978. The influence of a fungicide on the epidemiology of black shank of tobacco. Phytopathology 68:1760-1765.

Kapulnik, E., Quick, J., and DeVay, J. E. 1985. Germination of propagules of Verticillium dahliae in soil treated wtih methionine and other substances affecting ethylene production. (Abstr.) Phytopathology 75:1348.
Koike, S. T., Bolda, M. P., Gubler, W. D., and Bettiga, L. J. 2015. Verticillium Wilt. UC IPM Pest Managment Guidleines: Caneberries. Online publication. Univ. Calif. Agric. Nat. Resour. Publ. 3437. http://ipm.ucanr.edu/PMG/r71101011.html

Kroese, D. R., Weiland, J. E., and Zasada, I. A. 2016. Distribution and longevity of Pratylenchus penetrans in the red raspberry production system. J. Nematol. 48: 241-247.

Lawrence, W. H. 1912. Bluestem of the black raspberry. Bull. Wash. Agric. Exp. Stn. 108:1-30.

Lievens, B., Brouwer, M., Vanachter, A. C. R. C., Cammue, B. P. A., and Thomma, B. P. H. J. 2006. Real-time PCR for detection and quantification of fungal and oomycete tomato pathogens in plant and soil samples. Plant Sci. 171:155-165.

López-Escudero, F. J., Mwanza, C., and Blanco-Lopez, M. A. 2007. Reduction of Verticillium dahliae microsclerotia viability in soil by dried plant residues. Crop Prot. 26:127-133.

Martin, M. J., Riedel, R. M., and Rowe, R. C. 1982. Verticillium dahliae and Pratylenchus penetrans: Interactions in the early dying complex of potato in Ohio. Phytopathology 72:640-644.

Martin, R. R. 1998. Raspberry viruses in Oregon, Washington and British Columbia. Acta Hortic. 471:71-74.

McElroy, F. D. 1992. A plant health care program for brambles in the Pacific Northwest. J. Nematol. 24:457-462

Mercier, J., and Kong, M. 2017. Verticillium Wilt. Pages 56-58 in: Compendium of Raspberry and Blackberry Diseases and Pests, 2nd ed. R. R. Martin, M. A. Ellis, B. Williamson, and R. N. Williams, eds. American Phytopathological Society, St. Paul, MN.

Pleško, I. M., Marn, M. V., Širca, S., and Urek, G. 2009. Biologicial, serological and molecular characterization of Raspberry bushy dwarf virus from grapevines and its detection in the nematode Longidorus juvenilis. Eur. J. Plant Pathol. 123:261-268.

Quito-Avila, D. F., Lightle, D., and Martin, R. R. 2014. Effect of Raspberry bushy dwarf virus, Raspberry leaf mottle virus, and Raspberry latent virus on plant growth and fruit crumbliness in 'Meeker' red raspberry. Plant Dis. 98:176-183.

Rudolph, R. E., and DeVetter, L. W. 2015. Management strategies for Phytophthora rubi and Pratylenchus penetrans in floricane red raspberry (Rubus idaeus L.). J. Am. Pomol. Soc. 69:118-136.

Schilder, A. C., and Gillett, J. 2007. Determining the role of Rhizoctonia, Pythium, and Cylindrocarpon in replant disorder of raspberry. Pages 25-34 in: 2007 Conf. Proc. North Am. Bramble Grow. Assoc.

Sokal, R. R., and Rohlf, F. J. 2012. Biometry, 4th ed. W. H. Freeman and Company, New York.

Stewart, J. E., Kroese, D., Tabima, J. F., Larsen, M. M., Fieland, V. J., Press, C. M., Zasada, I. A., and Grünwald, N. J. 2014. Pathogenicity, fungicide resistance, and genetic variability of Phytophthora rubi isolates collected from raspberry (Rubus idaeus) in the Western United States. Plant Dis. 98:1702-1708.

Termorshuizen, A. J., Davis, J. R., Gort, G., Harris, D. C., Huisman, O. C., Lazarovits, G., Locke, T., Mellero Vara, J. M., Mol, L., and Paplomatas, E. J. 1998. Interlaboratory comparison of methods to quantify microsclerotia of Verticillium dahliae in soil. Appl. Environ. Microbiol. 64:3846-3853.

United States Department of Agriculture National Agricultural Statistics Service. 2017. Noncitrus fruits and nuts 2016 summary. http://usda.mannlib.cornell. edu/usda/current/NoncFruiNu/NoncFruiNu-06-27-2017.pdf

Walters, T. W., Bolda, M., and Zasada, I. A. 2017. Alternatives to current fumigation practices in western states raspberry. Plant Health Prog. 18:104-111.

Weber, R. W. S., and Entrop, A.-P. 2017. Dactylonectria torresensis as the main component of the black root rot complex of strawberries and raspberries in northern Germany. Erwerbs-Obstbau 59:157-169.

Weiland, J. E., Littke, W. R., Browning, J. E., Edmonds, R. L., Davis, A., Beck, B. R., and Miller, T. W. 2016. Efficacy of reduced rate fumigant alternatives and methyl bromide against soilborne pathogens and weeds in western forest nurseries. Crop Prot. 85:57-64.

Wilcox, W. F., and Cooke, D. E. L. 2017. Phytophthora root rot. Pages 52-56 in: Compendium of Raspberry and Blackberry Diseases and Pests, 2nd ed. R. R. Martin, M. A. Ellis, B. Williamson, and R. N. Williams, eds. American Phytopathological Society, St. Paul, MN.

Wilcox, W. F., Scott, P. H., Hamm, P. B., Kennedy, D. M., Duncan, J. M., and Brasier, C. M. 1993. Phytophthora fragariae var. rubi. Pages 332-333 in: Phytophthora Diseases Worldwide. D. C. Erwin and O. K. Ribiero, eds. American Phytopathological Society, St. Paul, MN.

You, R., Sweeney, M., Kempler, C., and Sabaratnam, S. 2006. Investigation of root rot complex on raspberries grown in the lower Fraser valley of British Columbia. (Abstr.) Can. J. Plant Pathol. 28:370.

Zasada, I. A., Pinkerton, J. N., and Neilson, R. 2017. Diseases caused by nematodes. Pages 93-96 in: Compendium of Raspberry and Blackberry Diseases and Pests, 2nd ed. R. R. Martin, M. A. Ellis, B. Williamson, and R. N. Williams, eds. American Phytopathological Society, St. Paul, MN.

Zasada, I. A., and Walters, T. W. 2016. Effect of application timing of oxamyl in nonbearing raspberry for Pratylenchus penetrans management. J. Nematol. 48: $177-182$.

Zasada, I. A., Weiland, J. E., Han, Z., Walters, T. W., and Moore, P. 2015. Impact of Pratylenchus penetrans on establishment of red raspberry. Plant Dis. 99 939-946.

Zeller, S. M. 1936. Verticillium wilt of cane fruits. Stn. Bull. Oreg. Agric. Coll. Exp. Stn. 344:1-25 